\title{
Retracted: A Prospective Study of Early Loaded Single Implant-Retained Mandibular Overdentures: Preliminary One-Year Results
}

\section{International Journal of Dentistry}

Received 5 August 2013; Accepted 5 August 2013

Copyright (C) 2013 International Journal of Dentistry. This is an open access article distributed under the Creative Commons Attribution License, which permits unrestricted use, distribution, and reproduction in any medium, provided the original work is properly cited.

The paper titled "A Prospective Study of Early Loaded Single Implant-Retained Mandibular Overdentures: Preliminary One-Year Results" [1], published in International Journal of Dentistry, has been retracted as it is found to contain a substantial amount of material from the paper "A prospective study of immediately loaded single implant-retained mandibular overdentures: preliminary one-year results," Liddelow G. J., Henry P. J., Journal of Prosthetic Dentistry, vol. 97, no. 6, pp. S126-S137, 2007.

\section{References}

[1] A. M. El-Sheikh, O. F. Shihabuddin, and S. M. F. Ghoraba, "A prospective study of early loaded single implant-retained mandibular overdentures: preliminary one-year results," International Journal of Dentistry, vol. 2012, Article ID 236409, 2012. 